\title{
Asymmetric Michael Addition with Amino Alcohol Catalysts Derived from D-Glucose
}

\author{
Feng Wang and Masahiro TADA* \\ Tokyo University of Agriculture and Technology, Laboratory of \\ Bio-organic Chemistry, Fuchu, Tokyo 183, Japan \\ Received June 18, 1990
}

\begin{abstract}
An enantioselective Michael addition of thiophenols to 2-cyclohexen-1-one was performed with catalysts of $\gamma$-amino alcohols that were synthesized from D-glucose. A linear relationship between the optical yield of this Michael addition and the specific rotation of the $\gamma$-amino alcohol catalysts was clearly observed.
\end{abstract}

The asymmetric Michael addition, which is catalyzed by chiral amines, is a very attractive reaction because of the increase in the amount of the chiral compound. ${ }^{1,2)}$ In the last decade, some results of the asymmetric Michael addition have been reported, using catalysts of natural alkaloids ${ }^{3-5)}$ or $\beta$-amino alcohols ${ }^{6}$ ) that were derived from $\alpha$-amino acids. Although carbohydrates are an easily available chiral resource, few catalysts of carbohydrate derivatives are known. We report here the synthesis of $y$-amino alcohols from D-glucose, and the results of the asymmetric Michael addition of thiophenols to enones catalyzed by these $\gamma$-amino alcohols (Scheme 1). A linear

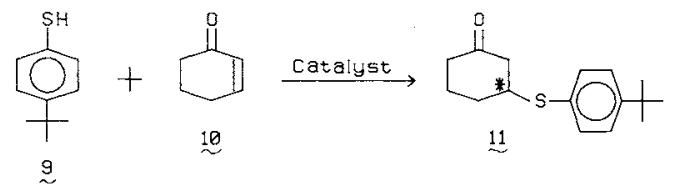

Scheme 1. relationship between the optical yield of the reaction and the specific rotation of the catalysts is also reported.

$\gamma$-Amino alcohols $(\mathbf{1}, \mathbf{2}, \mathbf{3}, \mathbf{4}$ and $\mathbf{5})$ were synthesized from D-glucose according to Scheme 2. Triacetylglucal ${ }^{8)}$ (6) was hydrogenated on $5 \% \mathrm{Pd} / \mathrm{C}$ in EtOAc, and the product was hydrolyzed in $10 \%-\mathrm{KOH}$ in $\mathrm{MeOH}$ to give 1,2-dideoxy-D-glucose $(7,85 \%),[\alpha]_{D}+11.6^{\circ}$ $\left(c=1.0\right.$, in $\left.\mathrm{H}_{2} \mathrm{O}\right)$. Successive reactions with triol 7, involving acetalization with $\mathrm{PhCHO}$ $\mathrm{ZnCl}_{2}$, etherification with $\mathrm{NaH}-\mathrm{C}_{6} \mathrm{H}_{5} \mathrm{CH}_{2} \mathrm{Br}$ in THF, deacetalization with $\mathrm{H}_{2} \mathrm{SO}_{4}$ in 2butanone and finally tosylation with $\mathrm{TsCl}$ in pyridine at $0^{\circ} \mathrm{C}$ for $8 \mathrm{hr}$, gave 1,2-dideoxy-3$O$-benzyl-6- $O$-tosyl-D-glucose $(8,62 \%$ from 7$)$, $[\alpha]_{\mathrm{D}}-10.4^{\circ}\left(c=1.0\right.$ in $\left.\mathrm{CHCl}_{3}\right)$. Treatment of tosylate 8 with $\mathrm{NaI}$ in 2-butanone at $100^{\circ} \mathrm{C}$ for $2 \mathrm{hr}$ and subsequently with an excess of secondary amines afforded $\gamma$-amino alcohols 1 (67\% from 8), 2 (64\%), $3(68 \%), 4(74 \%)$ and $5(73 \%)$.

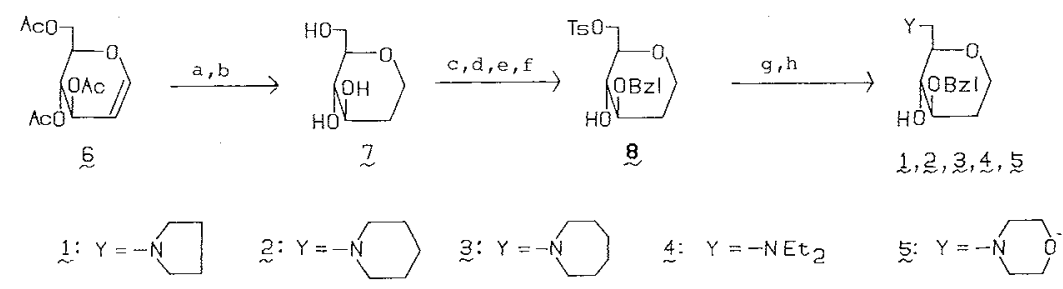

Scheme 2.

a) $\mathrm{H}_{2}, \mathrm{Pd} / \mathrm{C}$ in $\mathrm{AcOEt}$; b) $10 \%-\mathrm{KOH}, \mathrm{MeOH}$; c) $\mathrm{PhCHO}, \mathrm{ZnCl}_{2}$; d) $\mathrm{NaH}, \mathrm{C}_{6} \mathrm{H}_{5} \mathrm{CH}_{2} \mathrm{Br}$; e) $\mathrm{H}_{2} \mathrm{SO}_{4}$, 2-butanone;

f) $\mathrm{Ts} \mathrm{Cl}$, pyridine; g) NaI, 2-butanone; h) amines (YH) in 2-butanone (in EtOH or MeOH). 
Asymmetric Michael additions of 4-tertbutylthiophenol 9 (or thiophenol) to 2cyclohexen-1-one $\mathbf{1 0}$ catalyzed by amino alcohols 1, 2, 3, 4 and 5 in toluene were carried out at room temperature. The product was 3-(4-tert-butylphenylthio)cyclohexan-1-one 11 (77\% e.e.), $[\alpha]_{577}+40^{\circ}$ ( $c=1.0$ in benzene), which was purified easily by recrystallizing from pentane to afford white crystals of $(3 R)$ (4-tert-butylphenylthio)cyclohexan-1-one 11, $\mathrm{mp} 54^{\circ} \mathrm{C}$, and showing a larger specific rotation than the reported value. ${ }^{6,7)}$ The calculation of the optical yield was based on the values for the purified crystals of $\mathbf{1 1},[\alpha]_{577}+52^{\circ}(c=1.0$ in benzene), and the reported value for (3R)-phenylthiocyclohexan-1-one. ${ }^{7)}$ The results of the asymmetric Michael additions using each of these catalysts are shown in Table $\mathrm{I}$. The highest optical yield $(77 \%$ e.e. $)$ was obtained at $15-20^{\circ} \mathrm{C}$, in a nonpolar aprotic solvent, with $2.5 \mathrm{~mol} \%$ of amino alcohol 1 as the catalyst.

It was found that the optical yield from the Michael addition of 4-tert-butylthiophenol to 2-cyclohexen-1-one by each of the four catalysts was in inverse proportion to the optical

Table I. Asymmetric Michael Addition of Throls TO 2-CYCLOHEXEN-1-ONE CATALYZED BY AN $\gamma$-AMINO ALCOHOL

\begin{tabular}{|c|c|c|c|c|}
\hline Entry & Catalyst & Thiol $^{a}$ & $\begin{array}{c}\text { Addition products } \\
{[\alpha]_{577}(c=1 \text {, benzene })}\end{array}$ & $\%$ e.e. \\
\hline 1 & 2 & $\mathrm{~A}$ & +40 & 56 \\
\hline 2 & 1 & B & +40 & 77 \\
\hline 3 & 2 & $\mathrm{~B}$ & +29 & 56 \\
\hline 4 & 3 & B & +27 & 52 \\
\hline 5 & 4 & B & +23 & 44 \\
\hline 6 & 5 & B & +8 & 15 \\
\hline
\end{tabular}

a A, thiophenol; B, 4-tert-butylthiophenol.

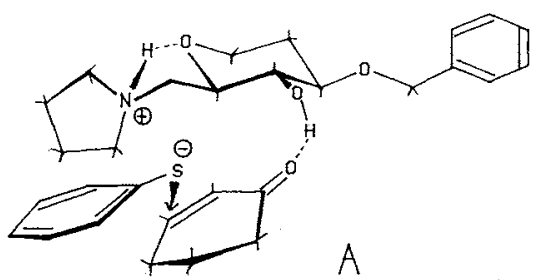

rotation of the catalyst (Fig. 1), except for catalyst 5 . Wynberg ${ }^{3)}$ and others ${ }^{67}$ have explained the mechanism for the base-catalyzed asymmetric Michael addition by considering the transition state model, in which the reagents are settled desirably by pairing the ammoniun ion with the thiol anion and by hydrogen bonding of the hydroxy group of the catalyst with the carbonyl group of the enone. A similar transition state model, conformation $\mathbf{A}$ on the $\gamma$-amino alcohol catalyst, can explain the mechanism for our asymmetric Michael addition reaction. A five-five ring spirocyclic structure can be formed in the transition state by hydrogen bonding of $\mathrm{N}-\underline{\mathrm{H}}$ with the cyclic ether oxygen, which may settle the conformation of the amino group of the catalyst. The thiol anion can attack the enone preferentially from the upper side in conformation $\mathbf{A}$ to give the $(3 R)$ Michael-addition product enantioselectively. In conformation $\mathbf{B}$, the thiol anion may attack the enone very slowly to give the $(3 S)$ product, because the thiol anion is located apart from the $\mathrm{C}-3$ carbon of the enone. It is interesting that the catalyst possessing a rigid

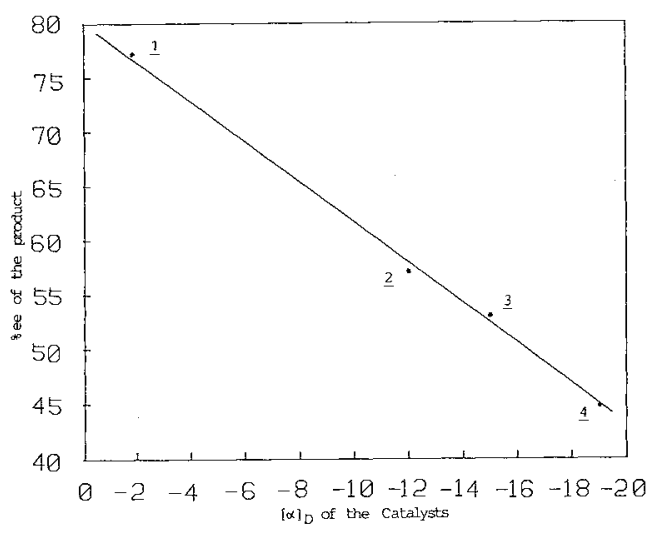

Fig. 1.

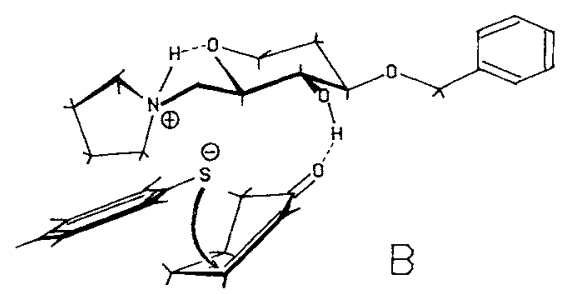

Fig. 2. 
amino group tended to give a smaller optical rotation and higher optical yield in our experiment. The catalyst with a rigid amino group can take a tight ion pair of the thiol anion with the ammonium ion in the transition state of Michael addition predominantly like A. Compound $\mathbf{5}$ may take a different conformation because of hydrogen bonding on the oxygen of the morpholino group.

In conclusion, $\gamma$-amino alcohol catalysts were sythesized from D-glucose, and used for asymmetric Michael additions. The absolute configuration of the products from these Michael additions agrees with the anticipated results from the mechanistic viewpoint.

\section{Experimental}

NMR spectra were measured with a JEOL GX-270 spectrometer in a $\mathrm{CDCl}_{3}$ solution containing tetramethylsilane as the internal standard. IR spectra were measured on a JASCO IR-810 spectrometer. Thin-layer chromatography was carried out on Kieselgel $\mathrm{GF}_{254}$ (Merck) of $0.25 \mathrm{~mm}$ thickness, and Wakogel C-200 (Wako Pure Chemical Industries) was used for column chromatography.

1,2-Dideoxy-D-glucose (7). A solution of $O$-triacetyl-Dglucal $(6,68.8 \mathrm{~g})$ in $200 \mathrm{ml}$ of ethyl acetate was stirred with $6.5 \mathrm{~g}$ of $\mathrm{Pd} / \mathrm{C}(5 \%)$ under an $\mathrm{H}_{2}$ atmosphere for $16 \mathrm{hr}$. The mixture was filtered through a Celite column, and the filtrate was evaporated to give $66.0 \mathrm{~g}$ of 1,2 -dideoxy- $O$ triacetyl-D-glucose (95\%). A mixture of this 1,2-dideoxy$O$-triacetyl-D-glucose $(10.5 \mathrm{~g}), 100 \mathrm{ml}$ of $10 \%-\mathrm{KOH}$ and $150 \mathrm{ml}$ of $\mathrm{MeOH}$ was stirred for $16 \mathrm{hr}$. The mixture was neutralized with $2 \mathrm{M}-\mathrm{HCl}$ and evaporated to give a residue, which was extracted with EtOH. The EtOH solution was evaporated to afford an oil of 1,2-dideoxy-D-glucose 7 $(6.2 \mathrm{~g}, 90 \%),[\alpha]_{\mathrm{D}} 11.6^{\circ}\left(c=1, \mathrm{H}_{2} \mathrm{O}\right)$; IR (neat) 3400 ; ${ }^{1} \mathrm{H}-\mathrm{NMR}\left(\mathrm{CDCl}_{3}\right) \delta 3.85(1 \mathrm{H}, \mathrm{m}), 3.60(4 \mathrm{H}, \mathrm{m}), 3.32(1 \mathrm{H}$, $\mathrm{m}), 3.14(1 \mathrm{H}, \mathrm{m}), \mathrm{I} .59(2 \mathrm{H}, \mathrm{m}) ;{ }^{13} \mathrm{C}-\mathrm{NMR}\left(\mathrm{CDCl}_{3}\right) \delta 87.70$, $75.20,68.00,64.30,59.80,19.85$.

3-O-Benzyl-6-O-tosyl-1,2-dideoxy-D-glucose (8). A mixture of dry triol $7(8 \mathrm{~g}), \mathrm{ZnCl}_{2}$ powder (40 g, freshly fused) and benzaldehyde ( $200 \mathrm{~g}$ ) was stirred under an $\mathrm{N}_{2}$ stream at reduced pressure for $12 \mathrm{hr}$. The mixture was neutralized by $\mathrm{I} \mathrm{M}-\mathrm{NaOH}$ and steam-distilled to remove the unreacted benzaldehyde. The distilled residual solution was extracted with $\mathrm{CHCl}_{3}$. The $\mathrm{CHCl}_{3}$ solution was evaporated in vacuo, and the product was purified by column chromatography on silica gel, eluting with hexane-EtOAc to give 4,6- $O$-benzylidene-1,2-dideoxy-D-glucose $(9.6 \mathrm{~g}, 75 \%)$.
A THF ( $30 \mathrm{ml}$ ) solution of this 4,6-O-benzylidene-1,2dideoxy-D-glucose $(0.562 \mathrm{~g})$ and the mixture was heated under reflux with $\mathrm{NaH}(0.286 \mathrm{~g})$ for $10 \mathrm{~min}$. Benzyl bromide $(0.815 \mathrm{~g})$ was added to the mixture, which was then heated under reflux for $23 \mathrm{hr}$. A small amount of water was added to the reaction mixture, which was then evaporated in vacuo to dryness. The product was extracted with water- $\mathrm{CHCl}_{3}$, and the organic solution was washed with brine and evaporated in vacuo. The product (the benzyl ether of 4,6-O-benzylidene-1,2-dideoxy-D-glucose $0.753 \mathrm{~g}$, $97 \%$ ) was purified by column chromatography (silica gel, hexane-EtOAc). The acetal group of the benzyl ether was removed by refluxing in a solution of 2-butanone $(20 \mathrm{ml})$ and $10 \%-\mathrm{H}_{2} \mathrm{SO}_{4}(4 \mathrm{ml})$ for $1.5 \mathrm{hr}$. The reaction mixture was neutralized with $5 \% \mathrm{NaHCO}_{3}$ and extracted with chloroform. The resulting organic solution was evaporated in vacuo, and the residue was chromatographed on silica gel with hexane-EtOAc to obtain $0.2473 \mathrm{~g}$ of $3-O-$-benzyl1,2-dideoxy-D-glucose $(97 \%)$.

A mixture of $0.2473 \mathrm{~g}$ of this 3-O-benzyl-1,2-dideoxy-Dglucose and $0.1985 \mathrm{~g}$ of tosyl chloride in $5 \mathrm{ml}$ of pyridine was stirred for $12 \mathrm{hr}$ at room temperature. The reaction mixture was poured into $100 \mathrm{ml}$ of water and extracted with chloroform. The chloroform solution was washed with $10 \%-\mathrm{HCl}$ and brine, and finally dried over anhydrous magnesium sulfate. The residue obtained by evaporating the solvent at reduced pressure was separated by silica gel TLC to give $0.3462 \mathrm{~g}$ of $8(85 \%) .8,[\alpha]_{\mathrm{D}}-10.44^{\circ}(c=1.0$ $\left.\mathrm{CHCl}_{3}\right)$; IR 3430, 3066, $1174 \mathrm{~cm}^{-1} ;{ }^{1} \mathrm{H}-\mathrm{NMR}\left(\mathrm{CDCl}_{3}\right) \delta$ $7.80(2 \mathrm{H}, \mathrm{d}, J=7.1 \mathrm{~Hz}), 7.35(7 \mathrm{H}, \mathrm{m}), 4.68(1 \mathrm{H}, \mathrm{d}$, $J=11.3 \mathrm{~Hz}), 4.56(1 \mathrm{H}, \mathrm{d}, J=11.3 \mathrm{~Hz}), 4.33(1 \mathrm{H}, \mathrm{dd}, J=2.1$, $9.8 \mathrm{~Hz}), 4.22(1 \mathrm{H}, \mathrm{m}), 3.95(1 \mathrm{H}, \mathrm{m}), 3.38(4 \mathrm{H}, \mathrm{m}), 2.42$ $(3 \mathrm{H}, \mathrm{s}), 2.02(1 \mathrm{H}, \mathrm{m}), 1.60(1 \mathrm{H}, \mathrm{m}) ;{ }^{13} \mathrm{C}-\mathrm{NMR}\left(\mathrm{CDCl}_{3}\right)$ $\delta 144.68,138.09,129.73,128.52,127.99,127.88,127.70$, $80.24,77.70,70.90,70.37,69.54,65.62,30.30,21.58$.

Catalysts 1, 2, 3, 4 and 5. A solution of 3-O-benzyl-6$O$-tosyl-1,2-dideoxy-D-glucose (139 mg, 8) and $\mathrm{NaI}(64 \mathrm{mg})$ in 2-butanone ( $15 \mathrm{ml})$ was refluxed for $3 \mathrm{hr}$. To the solution, pyrrolidine $(0.5 \mathrm{ml})$ was added, and the mixture was refluxed for $24 \mathrm{hr}$. The mixture was then extracted with EtOAc-water. The organic layer was washed with brine, dried and evaporated in vacuo. The product was purified by TLC to give amino alcohol 1 ( $72 \mathrm{mg}, 67 \%$ from 8 ), $[x]_{\mathrm{D}}-1.65^{\circ}(c=0.35$, EtOH $)$; IR $3208,3090 \mathrm{~cm}^{-1}$; ${ }^{1} \mathrm{H}-\mathrm{NMR} \delta 7.39(5 \mathrm{H}, \mathrm{m}), 4.83(1 \mathrm{H}, \mathrm{d}, J=11.7 \mathrm{~Hz}), 4.72$ $(1 \mathrm{H}, \mathrm{d}, J=11.7 \mathrm{~Hz}), 3.93(1 \mathrm{H}, \mathrm{m}), 3.45(4 \mathrm{H}, \mathrm{m}), 3.25(1 \mathrm{H}$, m), 2.55-2.7 (5H), $2.98(1 \mathrm{H}, \mathrm{dd}, J=10.5,10.3 \mathrm{~Hz}), 1.97$ $(2 \mathrm{H}, \mathrm{d}), 1.78(4 \mathrm{H}, \mathrm{s}) ;{ }^{13} \mathrm{C}-\mathrm{NMR} \delta 139.02,128.26,127.58$, $127.35,79.70,78.39,75.30,71.94,65.91,60.44,54.86,31.10$, 23.46.

Amino alcohols 2, 3 and 5 were synthesized by similar procedures. Amino alcohol $\mathbf{4}$ was obtained from 8 with diethylamine by refluxing in methanol for $30 \mathrm{hr}$.

2: $[\alpha]_{\mathrm{D}}-12.32^{\circ}(c=0.3, \mathrm{EtOH})$; IR $3210,3176 \mathrm{~cm}^{-1}$; ${ }^{1} \mathrm{H}-\mathrm{NMR} \delta 7.36(5 \mathrm{H}, \mathrm{m}), 4.82(1 \mathrm{H}, \mathrm{d}, J=10.5 \mathrm{~Hz}), 4.68$ $(1 \mathrm{H}, \mathrm{d}, J=10.5 \mathrm{~Hz}), 3.90(1 \mathrm{H}, \mathrm{m}), 3.42(4 \mathrm{H}, \mathrm{m}), 2.60(4 \mathrm{H}$, 
$\mathrm{m}), 2.38(2 \mathrm{H}, \mathrm{s}), 1.95(1 \mathrm{H}, \mathrm{m}) ;{ }^{13} \mathrm{C}-\mathrm{NMR} \delta 138.94,128.08$, $-127.45,127.16,79.50,78.14,77.23,73.59,71.74,65.69$, $63.49,55.42,30.95,25.75,23.72$.

3: $[\alpha]_{\mathrm{D}}-14.75^{\circ}(c=0.37, \mathrm{EtOH})$; IR 3174,2928 , $1095 \mathrm{~cm}^{-1} ;{ }^{1} \mathrm{H}-\mathrm{NMR} \quad \delta 7.35(5 \mathrm{H}, \mathrm{m}), 4.83(1 \mathrm{H}, \mathrm{d}$, $J=10.4 \mathrm{~Hz}), 4.69(1 \mathrm{H}, \mathrm{d}, J=10.4 \mathrm{~Hz}), 3.91(1 \mathrm{H}, \mathrm{m}), 3.53$ $(2 \mathrm{H}, \mathrm{m}), 3.38(1 \mathrm{H}, \mathrm{t}, J=11.2 \mathrm{~Hz}) ,3.21(1 \mathrm{H}, \mathrm{m}), 2.74(6 \mathrm{H}$, m), $1.98(1 \mathrm{H}, \mathrm{m}) ;{ }^{13} \mathrm{C}-\mathrm{NMR} \delta 139.11,128.22,127.62$, $127.30,79.70,78.53,74.36,71.79,65.89,63.48,56.98,31.07$, $27.60,26.62$.

4: $[\alpha]_{\mathrm{D}}-19.04^{\circ}(c=0.3, \mathrm{EtOH}) ;$ IR 3180,3090 , $1072 \mathrm{~cm}^{-1} ;{ }^{1} \mathrm{H}-\mathrm{NMR} \delta 7.35(5 \mathrm{H}, \mathrm{m}), 4.83(1 \mathrm{H}, \mathrm{d}$, $J=12.2 \mathrm{~Hz}), 4.72(1 \mathrm{H}, \mathrm{d}, J=12.2 \mathrm{~Hz}), 3.92(1 \mathrm{H}, \mathrm{m}), 3.49$ $(2 \mathrm{H}, \mathrm{m}), 3.40(1 \mathrm{H}, \mathrm{t}, J=9.8 \mathrm{~Hz}), 3.25(1 \mathrm{H}, \mathrm{dt}, J=9.0$, $9.0 \mathrm{~Hz}), 2.70(4 \mathrm{H}, \mathrm{q}, J=6.4 \mathrm{~Hz}), 2.45(2 \mathrm{H}, \mathrm{m}), 1.95(1 \mathrm{H}$, m), $1.65(1 \mathrm{H}, \mathrm{m}), 1.09(6 \mathrm{H}, \mathrm{t}, J=6.4 \mathrm{~Hz},) ;{ }^{13} \mathrm{C}-\mathrm{NMR} \delta$ $138.65,127.79,127.16,126.86,79.25,76.56,73.94,71.42$, $65.42,57.76,47.43,30.63,11.04$.

5: $[\alpha]_{\mathrm{D}}-5.50^{\circ} \quad(c=0.54$, benzene); IR 3190,3090 , $1115 \mathrm{~cm}^{-1} ;{ }^{1} \mathrm{H}-\mathrm{NMR} \delta 7.36(5 \mathrm{H}, \mathrm{m}), 4.76(1 \mathrm{H}, \mathrm{d}$, $J=12.5 \mathrm{~Hz}), 4.68(1 \mathrm{H}, \mathrm{d}, J=12.5 \mathrm{~Hz}), 3.95(1 \mathrm{H}, \mathrm{m}), 3.72$ $(4 \mathrm{H}, \mathrm{t}, J=4.5 \mathrm{~Hz}), 3.6-3.2(4 \mathrm{H}, \mathrm{m}), 2.68(4 \mathrm{H}, \mathrm{m}), 2.50(2 \mathrm{H}$, $\mathrm{m}), 2.00(1 \mathrm{H}, \mathrm{m}), 1.65(1 \mathrm{H}, \mathrm{m}) ;{ }^{13} \mathrm{C}-\mathrm{NMR} \delta 138.84,128.35$, $127.67,127.51,79.69,77.23,74.11,71.77,66.78,65.89$, $63.00,54.52,30.98$.

Asymmetric Michael addition. The typical procedure for the asymmetric Michael addition catalyzed by a chiral amino alcohol is as follows. A mixture of 4-tetrabutylthiophenol 9 ( $1 \mathrm{mmol})$, 2-cyclohexen-1-one $\mathbf{1 0}(0.8$ $\mathrm{mmol})$ and amino alcohol $1(0.02 \mathrm{mmol})$ in $2 \mathrm{ml}$ of toluene was stirred for $20 \mathrm{hr}$ at room temperature. The mixture was then extracted with benzene, and the organic solution was successively washed with $1 \mathrm{M}-\mathrm{HCl}, 1 \mathrm{M}-\mathrm{NaOH}$ and brine. The product was separated by $\mathrm{SiO}_{2}$-column chromatography, eluting with hexane-AcOEt, to afford 3-(4-tert-butylphenylthio)cyclohexan-1-one (11) of 77\% e.e., $[\alpha]_{577}+40^{\circ}(c=1.0$ in benzene) which was purified easily by recrystallization from pentane to afford white crystals of (3R)-(4-tert-butylphenylthio)cyclohexan-1-one, $\operatorname{mp~} 54^{\circ} \mathrm{C},[\alpha]_{577}+52^{\circ}(c=1.0$ in benzene $)$.

\section{References}

1) K. Hermann and H. Wynberg, J. Org. Chem., 44, 2238 (1979).

2) H. Wynberg, Top. Stereochem., 16, 87 (1986).

3) H. Hiemstra and H. Wynberg, J. Am. Chem. Soc., 103, 417 (1981).

4) H. Yamashita and T. Mukaiyama, Chem. Lett., 1985, 363.

5) A. Sera, K. Takagi, H. Katayama and H. Yamada, J. Org. Chem., 53, 1157 (1988).

6) T. Mukaiyama, A. Ikegawa and K. Suzuki, Chem. Lett., 1981, 165.

7) R. Helder, R. Arends, W. Bolt, H. Hiemstra and H. Wynberg, Tetrahedron Lett., 1977, 2181.

8) W. Roth and W. Pigman, "Methods in Carbohydrate Chemistry," Vol. II, Academic Press, New York, 1963, p. 405. 